\title{
Lactation modulates diurnal expression profiles of specific leptin receptor isoforms in the rat hypothalamus
}

\author{
R G P Denis ${ }^{1,2}$, C Bing ${ }^{1}$, E K Naderali ${ }^{1}$, R G Vernon ${ }^{2}$ \\ and $\mathbf{G}$ Williams ${ }^{1}$ \\ ${ }^{1}$ Diabetes and Endocrinology Research Group, Department of Medicine, The University of Liverpool, Liverpool, UK \\ ${ }^{2}$ Hannah Research Institute, Ayr, UK \\ (Requests for offprints should be addressed to G Williams, Diabetes and Endocrinology Research Group, Department of Medicine, The University of Liverpool, \\ Liverpool L9 7AL, UK; Email: g.williams@liverpool.ac.uk)
}

\begin{abstract}
We investigated the effects of lactation on diurnal changes in serum leptin and hypothalamic expression of the leptin receptor isoforms, $\mathrm{Ob}-\mathrm{Ra},-\mathrm{Rb},-\mathrm{Rc},-\mathrm{Re}$ and $-\mathrm{Rf}$ in rats. In non-lactating rats, serum leptin concentration was increased at night while hypothalamic mRNA levels of $\mathrm{Ob}-\mathrm{Rb},-\mathrm{Rc}$ and $-\mathrm{Re}$ decreased; by contrast, expression of $\mathrm{Ob}-\mathrm{Ra}$ and $\mathrm{Ob}-\mathrm{Rf}$ was unchanged at night. There were significant negative correlations between serum leptin and mRNA expression of $\mathrm{Ob}-\mathrm{Rb} \quad(P<0 \cdot 001)$ and $\mathrm{Ob}-\mathrm{Re}$ $(P<0 \cdot 05)$, which were independent of time of day. In lactating rats, the nocturnal rise in serum leptin was attenuated. Daytime hypothalamic Ob-Rb mRNA levels were significantly lower than in non-lactating controls, and the normal nocturnal decreases in expression of
\end{abstract}

Ob-Rb, -Rc and -Re were lost. The relationship between serum leptin and $\mathrm{Ob}-\mathrm{Re}$ expression was not changed by lactation. Lactation had no effect on the expression of $\mathrm{Ob}-\mathrm{Ra}$ mRNA in the hypothalamus. Decreased daytime $\mathrm{Ob}-\mathrm{Rb}$ expression could lead to reduced hypothalamic sensitivity to leptin, and thus contribute to increased daytime appetite in lactating rats. Moreover, maintaining high levels of Ob-Re expression could, by increasing hypothalamic leptin-binding protein concentration and reducing local leptin bioavailability, further accentuate hyperphagia. Thus, selective changes in expression of specific isoforms of the leptin receptor may contribute to the hyperphagia of lactation in rats.

Journal of Endocrinology (2003) 178, 225-232

\section{Introduction}

Lactation is a state of high energy demand, which, in rodents, is met primarily by increasing food intake severalfold (Wade \& Schneider 1992, Barber et al. 1997). Various other metabolic and hormonal changes serve to increase metabolic efficiency, both by channelling nutrients preferentially to the mammary gland and by decreasing energy expenditure in some tissues. Thus, for example, brown adipose tissue (BAT) thermogenesis is decreased (Trayhurn 1989) and animals also become hypothyroid and hypoinsulinaemic (Vernon \& Pond 1997). Nevertheless, lactating rats enter and remain in a state of negative energy balance, mobilising about $1 \mathrm{~g}$ fat/day up to the peak of lactation (Barber et al. 1997).

The factors that regulate the hyperphagia of lactation have not been resolved. The discovery of leptin, a $16 \mathrm{kDa}$ peptide produced and released by adipocytes (Zhang et al. 1994), introduced an additional and potentially important candidate. Leptin acts via receptors in the hypothalamus to decrease appetite and increase energy expenditure (Friedman \& Halaas 1998, Ahima 2000, Ahima \& Flier
2000, Ahima et al. 2000, Havel 2000, Spiegelman \& Flier 2001, Williams et al. 2001). Serum leptin concentrations decrease during periods of negative energy balance (Friedman \& Halaas 1998, Houseknecht et al. 1998, Ahima 2000, Vernon et al. 2001), and this would be predicted to increase hunger while decreasing energy expenditure.

Leptin receptors (Ob-R) are highly expressed in the hypothalamus (Fei et al. 1997). Six leptin receptor isoforms (Ob-Ra, Ob-Rb, Ob-Rc, Ob-Rd, Ob-Re and Ob-Rf), generated by alternative splicing, have been discovered to date (Ahima \& Flier 2000, Ahima et al. 2000, Meister 2000). All share a common extracellular ligand-binding domain at the amino terminus and all except Ob-Re have transmembrane domains, but differ in their intracellular carboxyl-terminal domains (Ahima \& Flier 2000, Ahima et al. 2000, Meister 2000). Only Ob-Rb contains all the intracellular motifs required for effective signalling via the JAK-STAT pathway, and is thought to be most important in modulating appetite (Ahima \& Flier 2000, Ahima et al. 2000, Meister 2000). Ob-Re, which lacks both transmembrane and intracellular domains, circulates as a soluble 
leptin-binding protein (Li et al. 1998, Huang et al. 2001). $\mathrm{Ob}-\mathrm{Ra}$ is thought to be important for the transport of leptin into the brain (Ahima \& Flier 2000, Ahima et al. 2001, Kastin \& Pan 2000). The functions of the other small isoforms (Ob-Rc, Ob-Rd and $\mathrm{Ob}-\mathrm{Rf}$ ) remain to be clarified, but they may interact with Ob-Rb (White et al. 1997).

Rats consume most food at night (Kimura et al. 1970, Bruckdorfer et al. 1974) and this pattern of behaviour is retained during lactation (Strubbe \& Gorissen 1980, Munday \& Williamson 1983, Pickavance et al. 1998). There are increases in adipocyte leptin mRNA and serum leptin levels at night (Saladin et al. 1995, Pickavance et al. 1998, Xu et al. 1999, Ahrén 2000, Mastronardi et al. 2000, Nagatani et al. 2000, Nishiyama et al. 2000, Pu et al. 2000), which are dependent on food intake (Saladin et al. 1995, Xu et al. 1999, Kalsbeek et al. 2001). The function of the nocturnal rise in leptin is uncertain as it should act to attenuate food intake. Most studies with lactating rats suggest that serum leptin concentration is decreased during the daytime (Kawai et al. 1997, Pickavance et al. 1998, Terada et al. 1998, Woodside et al. 1998, 2000, Brogan et al. 1999, Herrera et al. 2000, Johnstone \& Higuchi 2001, Denis et al. 2003), while the normal nocturnal increase in serum leptin is abolished or markedly attenuated (Pickavance et al. 1998, Johnstone \& Higuchi 2001, Denis et al. 2003). The decrease in serum leptin during lactation would be predicted to stimulate food intake and perhaps to decrease BAT thermogenesis.

Hypothalamic Ob receptors are clearly crucial in modulating leptin's effects on feeding, and there is some inconsistent evidence that lactation may affect daytime levels of certain Ob isoforms. Brogan et al. (2000) found decreased $\mathrm{Ob}-\mathrm{Rb}$ mRNA in the ventromedial hypothalamus (VMH) with lactation, with no significant changes in the arcuate nucleus (ARC), paraventricular nucleus or dorsomedial hypothalamus. By contrast, del Carmen Garcia et al. (2000) found an increase in hypothalamic Ob-Rf mRNA expression at peak lactation, whereas expression of other isoforms was unchanged.

Here, we investigated further the impact of lactation on hypothalamic levels of the mRNAs of five isoforms of the leptin receptor in the rat. As changes in serum leptin during lactation are more pronounced at night than during the day, animals were studied during both light and dark periods.

\section{Materials and Methods}

\section{Animals}

Female Wistar rats were raised at the Hannah Research Institute from stock obtained originally from A Tuck and Sons, Ltd (Rayleigh, Essex, UK). They were fed standard pelleted chow freely (CRM diet; Labsure, Poole, Dorset, UK) and had free access to water. One group $(n=16)$ was maintained on a light-darkness schedule with lights on from $0700 \mathrm{~h}$ to $1900 \mathrm{~h}$, and the other $(n=16)$ with light from $2200 \mathrm{~h}$ to $1000 \mathrm{~h}$. Eight from each group were mated at about 10 weeks of age, while the others were kept as non-lactating controls. Litter size of lactating rats was adjusted to ten pups within $24 \mathrm{~h}$ of parturition. After at least 4 weeks' exposure to the specific light-darkness regime, non-lactating and lactating (day 14 of lactation) rats were killed by cervical dislocation at $2 \mathrm{~h}$ into the light or dark phase. Food intake was measured over the last $24 \mathrm{~h}$ before killing.

Blood was collected and allowed to clot; serum was separated by centrifugation and stored at $-20{ }^{\circ} \mathrm{C}$ for later analysis of leptin concentrations. Parametrial white adipose tissue and brain were collected. The brain was frozen in liquid nitrogen and the hypothalamus later dissected en bloc under a binocular microscope, using consistent landmarks (Williams et al. 1988). The hypothalamic block was removed from a frontal slice of brain tissue between the optic chiasm and the mammillary bodies, using cuts made immediately below the anterior commissure and through the perihypothalamic sulci. The block was kept frozen in liquid nitrogen until mRNA extraction as described below.

All studies were conducted according to the UKCCR guidelines for the care and use of laboratory animals.

\section{Serum leptin}

Serum leptin concentration was determined by RIA using a commercial kit (Linco Research Inc., St Louis, MO, USA; distributed by Biogenesis, Poole, Dorset, UK).

\section{Quantitative RT-PCR}

RT-PCR was used to analyse the expression of isoformspecific Ob-Rb, Ob-Ra, Ob-Rc, Ob-Re and Ob-Rf mRNAs. Total RNA was extracted from frozen dissected hypothalami, using TriReagent (Sigma, Poole, Dorset, UK). The yield and quality of extracted RNA were assessed by the $260 / 280 \mathrm{~nm}$ optical density ratio and electrophoresis on $1.1 \%$ agarose gel. Only samples displaying satisfactory quality were used for analysis. Total RNA was treated with RNase-free DNase I (Roche, Lewes, East Sussex, UK) for $10 \mathrm{~min}$ at $37^{\circ} \mathrm{C}$ and a further $10 \mathrm{~min}$ at $75{ }^{\circ} \mathrm{C}$.

Reverse transcription was carried out using optimised amounts $(1 \mu \mathrm{g})$ of total RNA with a Reverse-iT 1st Strand Synthesis Kit (Abgene, Epsom, Surrey, UK) in a final volume of $25 \mu \mathrm{l}$. First-strand cDNA was used for PCR amplification of the target genes using the following primers (obtained from Sigma-Genosys Ltd, Pampisford, Cambridgeshire, UK): Ob-Ra, 5'-CCTATCGAGAA ATATCGTTTA- $3^{\prime}$ and $5^{\prime}$-TCAAAGAGTGTCCCT CTCT-3' corresponding to a 284-bp sequence (del Carmen Garcia et al. 2000, GenBank: D84126); 


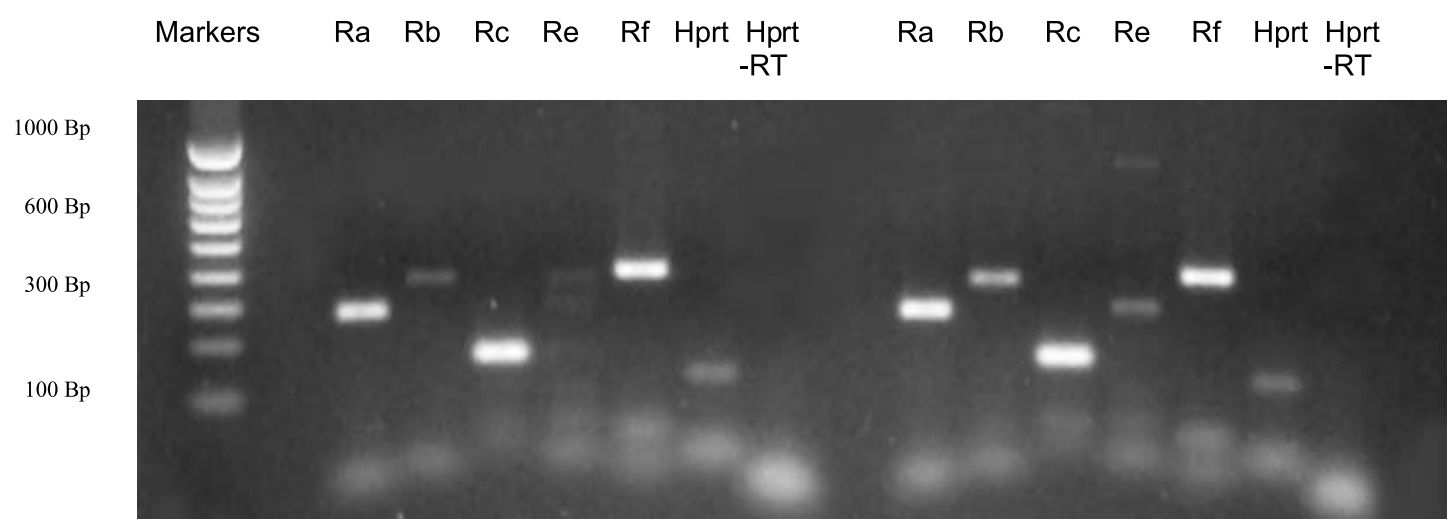

Figure 1 Separation of RT-PCR products by agarose electrophoresis of Ob-R isoforms and the housekeeping gene HPRT from hypothalamus of rat. Results for two sets of preparations from two different rats shown. Negative controls, in which no reverse transcriptase was included, are also shown (HPRT - RT).

Ob-Rb, 5'-TATGTCATTGTACCGATAATTATT-3' and 5'-CAGAGAAGTTAGCACTGTT-3' corresponding to a 370-bp sequence (Wang et al. 1996, GenBank: AF287268); Ob-Rc, 5'-ATTGTACCGGTAATTAT TTCCT-3' and $5^{\prime}-C T G C A A C C T T A G A T A T C T T G G-$ $3^{\prime}$ corresponding to a 180-bp sequence (del Carmen Garcia et al. 2000, GenBank: AF007818); Ob-Re, 5'GCAGAATCAGCACACACTGTT-3' and 5'-GTAA AAGCACACAGTACACATACC-3' corresponding to a $297 \mathrm{bp}$ sequence (del Carmen Garcia et al. 2000, GenBank: AF007819); Ob-Rf, 5'-TATGTCATTGT ACCGATAATTATT-3' and GGGTACCTGCACA CATATGTG-3' corresponding to a $389 \mathrm{bp}$ sequence (Wang et al. 1996, GenBank: U53144). Housekeeping gene HPRT (hypoxanthine-guanine phosphoribosyltransferase, Siegling et al. (1994)) was also amplified using 5'-CAGTCCCAGCGTCGTGATTA-3' and 5'-AGC AAGTCTTTCAGTCCTGTC-3' corresponding to a 138 bp sequence (GenBank: X62085).

PCR was performed with $1 \mu \mathrm{l}$ template cDNA and $35 \mu \mathrm{l}$ PCR mix $(1.1 \times$ ReddyMix PCR master mix, $1.5 \mathrm{mM} \mathrm{MgCl} 2$; ABgene) on a thermal cycler (Hybaid, Ashford, Kent, UK). After initial denaturation at $94{ }^{\circ} \mathrm{C}$ for $5 \mathrm{~min}$, the samples were subjected to cycles of amplification: denaturation at $94{ }^{\circ} \mathrm{C}$ for $30 \mathrm{~s}$, annealing at $54^{\circ} \mathrm{C}$ for $\mathrm{Ob}-\mathrm{Ra},-\mathrm{Rb},-\mathrm{Rc},-\mathrm{Rf}$ and HPRT and $56^{\circ} \mathrm{C}$ for Ob-Re for $30 \mathrm{~s}$, and extension at $72{ }^{\circ} \mathrm{C}$ for $40 \mathrm{~s}$. According to preliminary PCR experiments (data not shown) the optimised cycles of amplification within linear range were used for each gene: 24 cycles for HPRT, 36 cycles for $\mathrm{Ob}-\mathrm{Re}$ and 34 cycles for the other isoforms. Final extension was performed at $72{ }^{\circ} \mathrm{C}$ for $7 \mathrm{~min}$. Negative controls without reverse transcriptase were systematically performed to detect cDNA contamination. PCR products were subjected to electrophoresis on a $1 \cdot 1 \%$ agarose gel (Fig. 1). Bands were visualised and quantified using a digital image analysis system (Kodak 1-D; Kodak Eastman, Rochester, NY, USA). Optical density was calculated for each $\mathrm{Ob}-\mathrm{R}$ product and the results expressed as the ratio of its density to that of the HPRT product.

\section{Adipocyte cell volume}

Adipocytes were prepared by collagenase digestion and adipocyte mean cell volume was determined as described previously (Robertson et al. 1982).

\section{Statistical analyses}

Results are expressed as means \pm S.E.M. and were analysed by ANOVA followed by Tukey's test, with physiological state, light/dark phase and their interactions as factors. Degrees of linear relationship between two variables were performed using Genstat (Genstat 4·2, 5th edition; Lawes Agricultural Trust, VSN International Ltd, Oxford, UK). A $P$ value of 0.05 or less was considered as significant.

\section{Results}

Food intake per day was $14.3 \pm 1.7$ and $58.2 \pm 3.8 \mathrm{~g} / \mathrm{rat}$ for non-lactating and lactating rats respectively $(P<0 \cdot 001)$. Adipocyte mean cell volume did not alter with the light phase, but decreased significantly during lactation $(P<0 \cdot 02)$ (Table 1). ANOVA showed that for serum leptin concentration there was a significant statelight/dark phase interaction $(P<0 \cdot 05)$. Lactation had no significant effect on serum leptin concentration during the light phase, but the nocturnal increase $(P<0 \cdot 001)$ in leptin, which was apparent in both states, was significantly diminished $(P<0 \cdot 01)$ by lactation (Table 1$)$.

Expression of $\mathrm{Ob}-\mathrm{R}$ isoforms in the hypothalamus

Neither lactation nor light/dark phase had a significant effect on hypothalamic Ob-Ra mRNA expression 
Table 1 Serum leptin concentrations and adipocyte mean cell volume of lactating and non-lactating rats at $2 \mathrm{~h}$ into the light or darkness period. Values are expressed as means \pm S.E.M. from ANOVA of eight observations

\begin{tabular}{|c|c|c|c|c|}
\hline & \multicolumn{2}{|l|}{ Lactating } & \multicolumn{2}{|l|}{ Non-lactating } \\
\hline & Light & Dark & Light & Dark \\
\hline Leptin $(\mathrm{ng} / \mathrm{ml})$ & $1 \cdot 55 \pm 0 \cdot 22^{\mathrm{a}}$ & $2 \cdot 53 \pm 0 \cdot 22^{b}$ & $1 \cdot 81 \pm 0 \cdot 22^{\mathrm{a}}$ & $3 \cdot 79 \pm 0 \cdot 22^{\mathrm{C}}$ \\
\hline Adipocyte volume (pl) & $244 \pm 32^{\mathrm{a}}$ & $286 \pm 32^{\mathrm{ac}}$ & $311 \pm 32^{\mathrm{bc}}$ & $379 \pm 32^{b}$ \\
\hline
\end{tabular}

Values in a row without the same letter $(\mathrm{a}, \mathrm{b}, \mathrm{c})$ differ significantly $(P<0 \cdot 05)$.

$(P=0.10$ for state, $P=0.31$ for light $/$ dark phase, $P=0.74$ for their interaction) (Fig. 2a). By contrast, hypothalamic $\mathrm{Ob}-\mathrm{Rb} \mathrm{mRNA}$ exhibited a highly significant interaction between state and light/dark phase $(P<0 \cdot 001)$ (Fig. 2b). In non-lactating rats, hypothalamic Ob-Rb mRNA levels were $50 \%$ lower during the dark phase than in the light $(P<0 \cdot 001)$. In lactating rats, hypothalamic $\mathrm{Ob}-\mathrm{Rb}$ mRNA concentration was lower during the light phase than in non-lactating rats $(P<0 \cdot 001)$, and the hypothalamic $\mathrm{Ob}-\mathrm{Rb}$ mRNA concentration did not differ significantly between light and dark phases. During the dark phase, hypothalamic Ob-Rb mRNA levels were significantly greater in lactating than in non-lactating rats $(P<0 \cdot 01)$.

Expression of hypothalamic Ob-Rc mRNA also showed a significant interaction between state and light/ dark phase $(P<0 \cdot 01)$ (Fig. 2c). In non-lactating rats, hypothalamic Ob-Rc mRNA levels were 30\% lower during the dark than in the light phase $(P<0 \cdot 05)$. In the lactating group, Ob-Rc mRNA did not differ significantly with light/dark phase.

Hypothalamic Ob-Re expression was decreased during the dark phase in non-lactating rats $(P<0.05)$, but did not change with light/dark phase in lactating rats (Fig $2 \mathrm{~d}$ ). $\mathrm{Ob}-\mathrm{Re}$ expression, was not altered by lactation in the light phase, but expression was higher during the dark phase in lactating compared with non-lactating rats $(P<0 \cdot 05)$.

ANOVA showed that there was no significant effect of light/dark phase on hypothalamic Ob-Rf expression (Fig. $2 \mathrm{e})$. Ob-Rf expression in the dark phase was greater $(P<0 \cdot 05)$ in lactating compared with non-lactating rats, but light-phase expression was similar in both groups (Fig. 2e).

\section{Relationship of $\mathrm{Ob}-\mathrm{R}$ isoform expression with leptin}

In non-lactating rats, there was a significant negative correlation between serum leptin and hypothalamic Ob-Rb mRNA levels $(r=-0 \cdot 82, P<0 \cdot 001)$ (Fig. 3). This correlation was absent in lactating rats $(r=0 \cdot 49$, $P=0.13$ ); furthermore, when data for non-lactating and lactating rats were pooled, the correlation was weaker $(r=-0 \cdot 44, \quad P<0 \cdot 05)$ than within the non-lactating group alone.

Similarly, there was a significant correlation $(r=-0 \cdot 57$, $P<0.05)$ between serum leptin and hypothalamic Ob-Re
mRNA expression in non-lactating, but not in lactating rats (Fig. 4). However, combining data from both groups strengthened the correlation between serum leptin and hypothalamic Ob-Re mRNA as compared with nonlactating rats alone $(r=-0.61, P<0 \cdot 001)$.

There were no significant correlations between serum leptin concentration and either $\mathrm{Ob}-\mathrm{Ra}, \mathrm{Ob}-\mathrm{Rc}$ or $\mathrm{Ob}-\mathrm{Rf}$ (data not shown).

\section{Discussion}

This study shows that there are diurnal changes in the expression of specific isoforms of the leptin receptor in the hypothalamus, and that some of these changes are modulated by lactation.

\section{Normal diurnal changes in serum leptin and hypothalamic leptin receptor expression}

As already mentioned, fed rodents normally show nocturnal increases in adipocyte leptin mRNA expression (Saladin et al. 1995, Pickavance et al. 1998, Xu et al. 1999) and serum leptin concentration (Pickavance et al. 1998, Xu et al. 1999, Ahrén 2000, Mastronardi et al. 2000, Nagatani et al. 2000, Nishiyama et al. 2000, Pu et al. 2000), these rises being dependent on food intake (Saladin et al. 1995, Xu et al. 1999, Kalsbeek et al. 2001). This diurnal pattern was confirmed in the non-lactating female rats of the present study (Table 1).

We also found diurnal changes in the hypothalamic expression of specific Ob-R isoforms (but not others) in our non-lactating female rats. There were significant nocturnal decreases in mRNAs for $\mathrm{Ob}-\mathrm{Rb},-\mathrm{R} c$ and $-\mathrm{Re}$, but not of Ob-Ra or Ob-Rf. A nocturnal fall in hypothalamic Ob-R mRNA levels has previously been reported in normal rats by Xu et al. (1999) and appeared to follow the night-time rise in plasma leptin; however, the Ob-R isoform(s) recognised by the probe were not identified by $\mathrm{Xu}$ et al. (1999), and ours is the first study to examine the major isoforms individually.

The factors responsible for the decreased expression of $\mathrm{Ob}-\mathrm{Rb},-\mathrm{Rc}$ and $-\mathrm{Re}$ during the dark have not been identified, but for $\mathrm{Ob}-\mathrm{Rb}$ and $\mathrm{Ob}-\mathrm{Re}$ the rise in serum leptin probably contributes. Leptin appears to modulate $\mathrm{Ob}-\mathrm{Rb}$ levels in various tissues, including the hypothalamus, both by inducing down-regulation of the receptor 
(a)

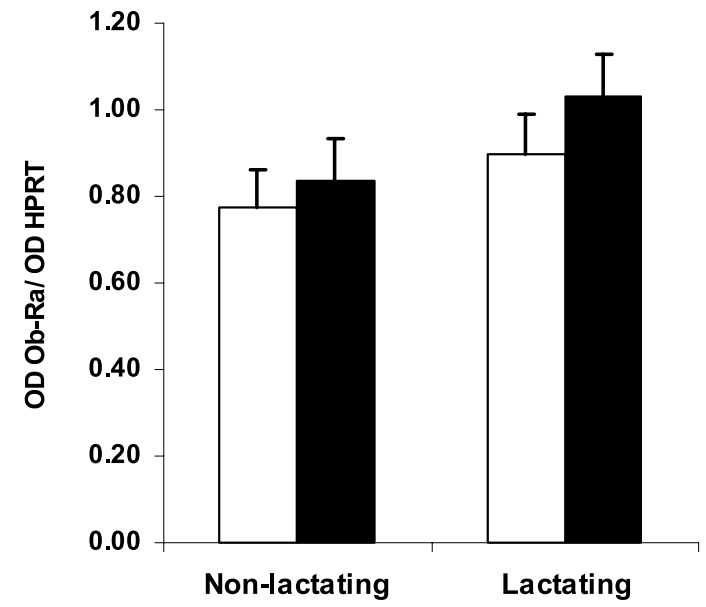

(C)

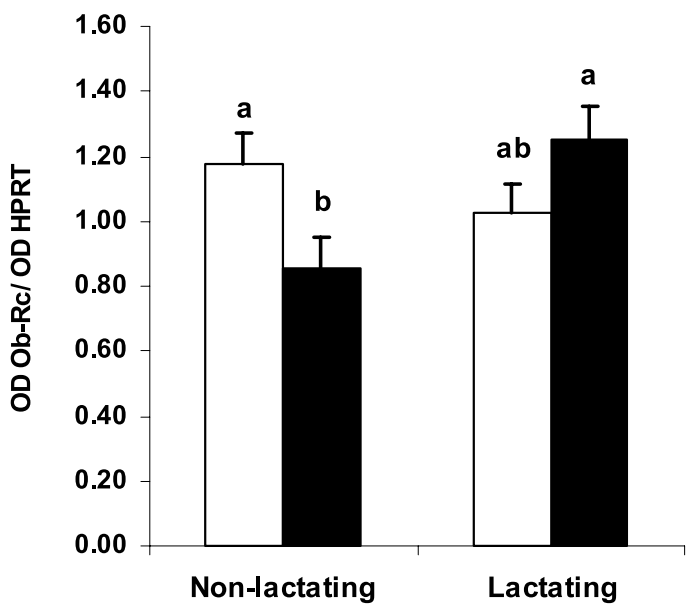

(e)

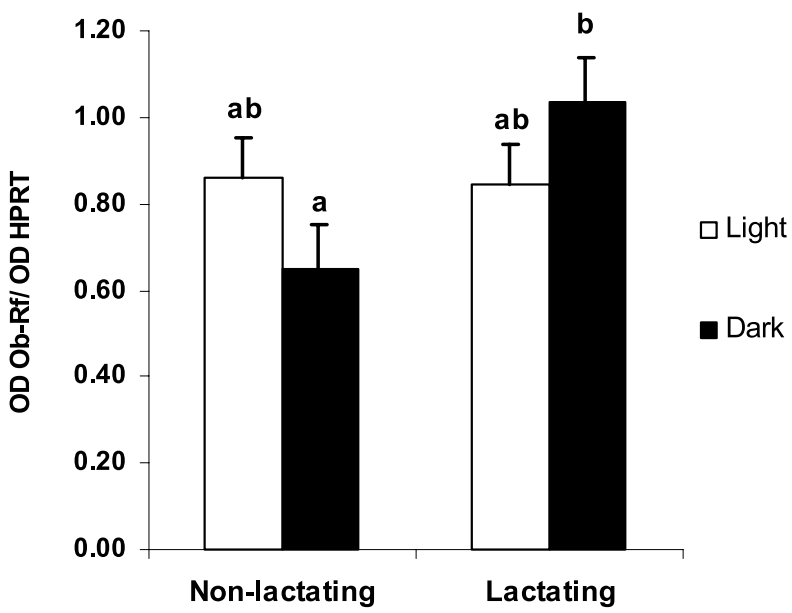

(b)

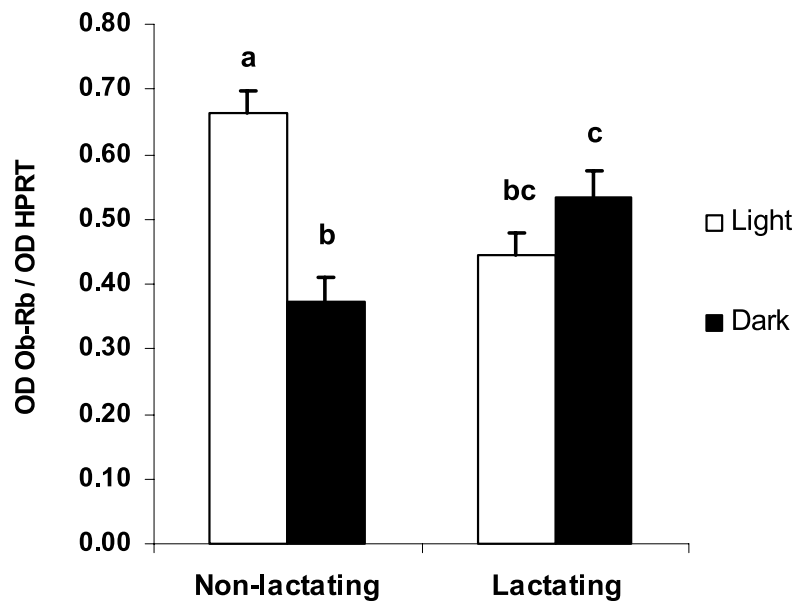

(d)

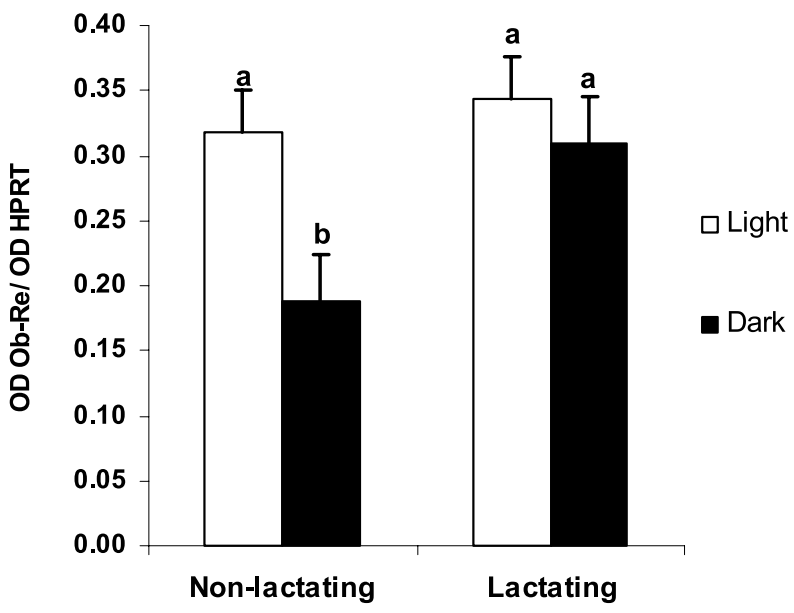

Figure 2 Amount of hypothalamic Ob-Ra mRNA (a), Ob-Rb mRNA (b), Ob-Rc mRNA (c), Ob-Re mRNA (d) and Ob-Rf mRNA (e) relative to HPRT mRNA in lactating and non-lactating rats in the light and dark phase. Values are means \pm S.E.M., obtained from ANOVA, of seven and six observations for non-lactating and lactating rats respectively, except for $\mathrm{Ob}-\mathrm{Rb}$ for lactating rats in the dark, for which the value is a mean of five observations. There were no significant differences between values for Ob-Ra; for other variables values (bars) without the same labels $(\mathrm{a}, \mathrm{b}$ or $\mathrm{c}$ ) differ significantly $(P<0 \cdot 05)$. 


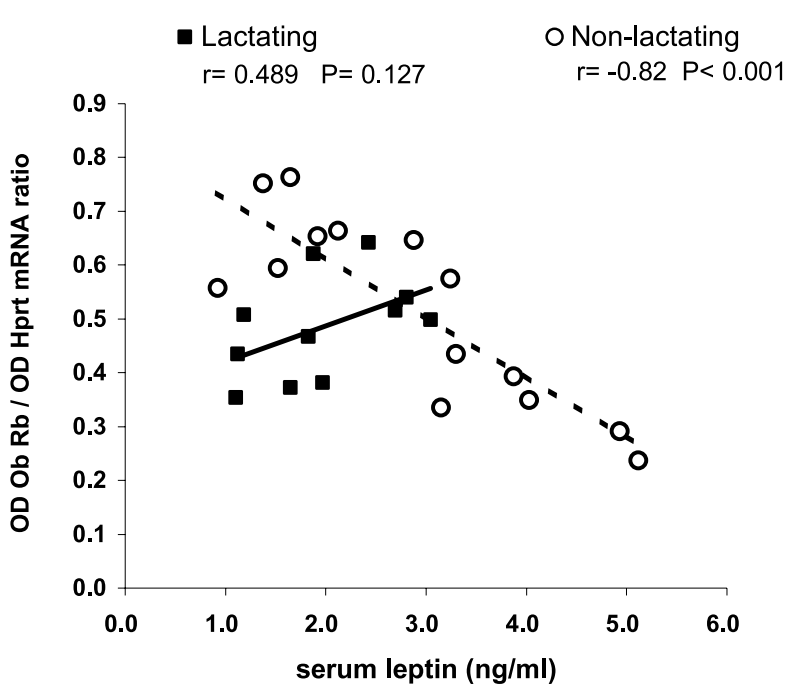

Figure 3 Amount of Ob-Rb mRNA relative to HPRT mRNA concentration in the hypothalamus plotted against serum leptin concentration for lactating and non-lactating rats.

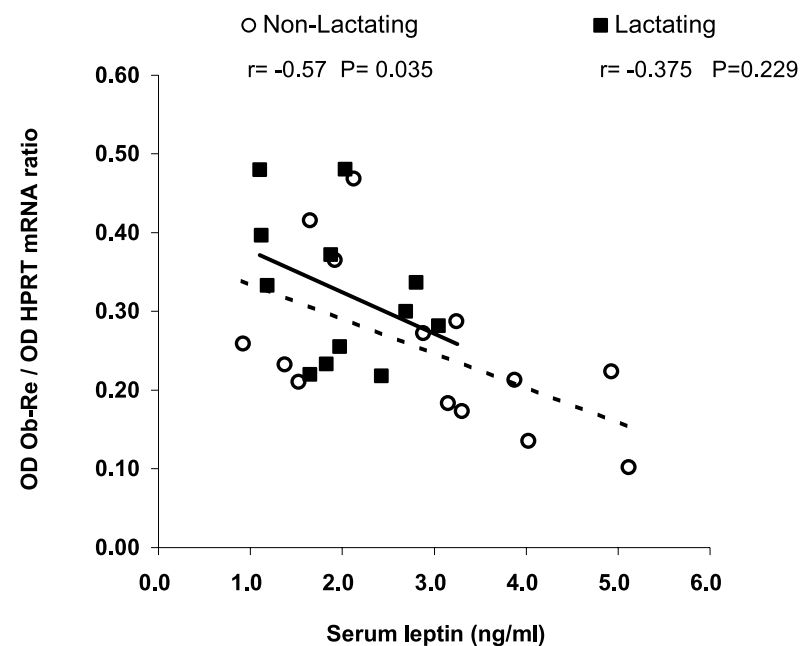

Figure 4 Amount of Ob-Re mRNA relative to HPRT mRNA concentration in the hypothalamus plotted against serum leptin concentration for lactating and non-lactating rats.

protein (Barr et al. 1999, Uotani et al. 1999, Martin et al. 2000) and by decreasing expression of $\mathrm{Ob}-\mathrm{Rb} \mathrm{mRNA}$ (Mercer et al. 1997, Hikita et al. 2000, Martin et al. 2000, Tena-Sempere et al. 2000, 2001). Consistent with this, the falls in serum leptin induced by fasting (Baskin et al. 1998) and cold-exposure (Mercer et al. 1997, Hardie et al. 1996), and the increase in serum leptin during pregnancy (del Carmen Garcia et al. 2000) are all associated with reciprocal changes in hypothalamic Ob-Rb expression. Baskin et al. (1998) proposed that an increase in hypothalamic $\mathrm{Ob}-\mathrm{Rb}$ mRNA will result ultimately in enhanced sensitivity to leptin. If so, then the nocturnal fall in $\mathrm{Ob}-\mathrm{Rb}$ expression should decrease sensitivity to the night-time rise in leptin levels, and so tend to offset the diurnal changes in plasma leptin.

$\mathrm{Ob}-\mathrm{Re}$ is expressed in many tissues (Lollmann et al. 1997), but lacks both transmembrane and intracellular domains and is released into the circulation where it acts as a leptin-binding protein ( $\mathrm{Li}$ et al. 1998). Consistent with such a role, overexpression of $\mathrm{Ob}-\mathrm{Re}$ in vivo led to increased serum leptin concentrations due to decreased clearance of leptin (Huang et al. 2001). Leptin, however, decreases the serum concentration of its soluble receptor in rats (Huang et al. 2001). Also, there are reciprocal diurnal changes in serum leptin and its soluble receptor in humans (Chan et al. 2002). We found that hypothalamic Ob-Re mRNA level varies inversely with serum leptin concentration during the light and dark phases. It is possible that $\mathrm{Ob}-\mathrm{Re}$ acts as a leptin-binding protein within the extracellular fluid of the hypothalamus or even the cerebrospinal fluid; this might be expected to reduce the local bioavailability of leptin, in which case the central effects of high and low leptin levels would be accentuated.

\section{Effects of lactation on hypothalamic leptin receptors}

Most previous studies agree that lactation decreases serum leptin and abolishes or at least markedly attenuates the normal nocturnal rise (Kawai et al. 1997, Pickavance et al. 1998, Terada et al. 1998, Woodside et al. 1998, 2000, Brogan et al. 1999, Herrera et al. 2000, Johnstone \& Higuchi 2001, Denis et al. 2003), although two reports found no effect on daytime serum leptin (Chien et al. 1997, del Carmen Garcia et al. 2000). The reason for the lack of a significant decrease in daytime serum leptin during lactation in the present study is not clear. However, the decrease in adipocyte mean cell volume with lactation in the present study was less than in a previous study (Pickavance et al. 1998), in which a significant decrease in daytime leptin was observed in lactating rats. This suggests that the degree of negative energy balance of the lactating rats is less than in our previous study. Overall, hypoleptinaemia would be expected to facilitate the hyperphagia of lactation.

$\mathrm{Ob}-\mathrm{Rb}$, the long isoform thought to be crucially involved in decreasing appetite (Ahima \& Flier 2000, Ahima et al. 2000, Meister 2000), shows reciprocal changes in expression following alterations in serum leptin, in various states including fasting, cold-exposure and pregnancy (see above). Intriguingly, this inverse relationship between serum leptin and hypothalamic Ob-Rb mRNA expression is lost during lactation (Figs. $2 \mathrm{~b}$ and 3 ). The daytime decrease in hypothalamic $\mathrm{Ob}-\mathrm{Rb} \mathrm{mRNA}$ compared with non-lactating rats is consistent with the reduced expression in the $\mathrm{VMH}$ (and a tendency to decrease in the ARC) reported by Brogan et al. (2000), but not with the unchanged whole-hypothalamic levels described by del Carmen Garcia et al. (2000). A decrease in daytime $\mathrm{Ob}-\mathrm{Rb}$ expression during lactation cannot be 
obviously attributed to an increase in leptin (which is usually lower than in non-lactating rats); additional factors regulating expression of this receptor are thus implicated. If, as proposed for other states by Baskin et al. (1998), decreased hypothalamic Ob-Rb mRNA expression during lactation diminishes sensitivity to leptin during the daytime, then this might also contribute to the hyperphagia of lactation. By contrast to $\mathrm{Ob}-\mathrm{Rb}$ expression, the reciprocal relationship between serum leptin and hypothalamic Ob-Re expression does not appear to be altered by lactation.

Our finding that expression of $\mathrm{Ob}-\mathrm{Ra}$ (which may be involved in leptin transport into the brain) (Bjorbaek et al. 1998, Kastin \& Pan 2000) in the hypothalamus was unaltered by lactation is consistent with that of del Carmen Garcia et al. (2000). The functions of the short isoforms, $\mathrm{Ob}-\mathrm{Rc}$ and $\mathrm{Ob}-\mathrm{Rf}$, are still not clear, but are postulated to include involvement in the transport of leptin across the blood-brain barrier (Guan et al. 1997) and the modulation of leptin signalling via Ob-Rb (White et al. 1997). Expression of both isoforms showed marked diurnal rhythms similar to that of $\mathrm{Ob}-\mathrm{Rb}$, which again were lost during lactation. The lack of effect of lactation on $\mathrm{Ob}-\mathrm{Rc}$ expression during the light phase is consistent with the finding of del Carmen Garcia et al. (2000), but unlike these authors, we found no increase in Ob-Rf expression during the light phase in lactation; the reason for this difference is not clear.

\section{Conclusions}

Several factors may contribute to the sustained hyperphagia of lactation, and their importance may vary with time of day. Hypoleptinaemia, especially at night when food intake is greatest, seems likely to be important; theoretically, this effect could be accentuated by reciprocal increases in Ob-Re, which may reduce leptin's bioavailability. Moreover, the normal inverse relationship between serum leptin and hypothalamic $\mathrm{Ob}-\mathrm{Rb}$ mRNA expression is lost during lactation. Diminished $\mathrm{Ob}-\mathrm{Rb}$ expression during the daytime may decrease sensitivity to leptin, which should also favour the hyperphagia. Thus, hyperphagia during lactation may be accentuated by multifactorial decreases in hypothalamic leptin sensitivity as well as hypoleptinaemia. The factors responsible for hypoleptinaemia and the altered relationships between serum leptin and hypothalamic $\mathrm{Ob}-\mathrm{Rb}$ mRNA expression during lactation have yet to be resolved.

\section{Acknowledgements}

This study was supported financially by the Scottish Executive Environment and Rural Affairs Department. We thank Dr Peter Collins for assistance with the RTPCR technique and Sandra Patton and Sandy MacBlane for animal care.

\section{References}

Ahima RS 2000 Leptin and the neuroendocrinology of fasting. Frontiers of Hormone Research 26 42-56.

Ahima RS \& Flier JS 2000 Leptin. Annual Review of Physiology 62 413-437.

Ahima RS, Saper CB, Flier JS \& Elmquist JK 2000 Leptin regulation of neuroendocrine systems. Frontiers in Neuroendocrinology 21 263-307.

Ahrén B 2000 Diurnal variation in circulating leptin is dependent on gender, food intake and circulating insulin in mice. Acta Physiologica Scandinavica 169 325-331.

Barber MC, Clegg RA, Travers MT \& Vernon RG 1997 Lipid metabolism in the lactating mammary gland. Biochimica et Biophysica Acta 1347 101-126.

Barr VA, Lane K \& Taylor SI 1999 Subcellular localization and internalization of the four human leptin receptor isoforms. Journal of Biological Chemistry 274 21416-21424.

Baskin DG, Seeley RJ, Kuijper JL, Lok S, Weigle DS, Erickson JK, Palmiter RD \& Schwartz MW 1998 Increased expression of mRNA for the long form of the leptin receptor in the hypothalamus is associated with leptin hypersensitivity and fasting. Diabetes 47 538-543.

Bjorbaek C, Elmquist JK, Michl P, Ahima RS, van Bueren A, McCall AL \& Flier JS 1998 Expression of leptin receptor isoforms in rat brain microvessels. Endocrinology 139 3485-3491.

Brogan RS, Mitchell SE, Trayhurn P \& Smith MS 1999 Suppression of leptin during lactation: contribution of the suckling stimulus versus milk production. Endocrinology 140 2621-2627.

Brogan RS, Grove KL \& Smith MS 2000 Differential regulation of leptin receptor but not orexin in the hypothalamus of the lactating rat. Journal of Neuroendocrinology 12 1077-1086.

Bruckdorfer KR, Kang SS, Khan IH, Bourne AR \& Yudkin J 1974 Diurnal changes in the concentrations of plasma lipids, sugars, insulin and corticosterone in rats fed diets containing various carbohydrates. Hormone and Metabolic Research 6 99-106.

del Carmen Garcia MD, Casanueva FF, Dieguez C \& Senaris RM 2000 Gestational profile of leptin messenger ribonucleic acid (mRNA) content in the placenta and adipose tissue in the rat, and regulation of the mRNA levels of the leptin receptor subtypes in the hypothalamus during pregnancy and lactation. Biology of Reproduction 62 698-703.

Chan JL, Blüher S, Yiannakouris N, Suchard MA, Kratzsch J \& Mantzoros CS 2002 Regulation of circulating soluble leptin receptor levels by gender, adiposity, sex steroids, and leptin. Diabetes 51 2105-2112.

Chien EK, Hara M, Rouard M, Yano H, Phillipe M, Polonsky KS \& Bell GI 1997 Increase in serum leptin and uterine leptin receptor messenger RNA levels during pregnancy in rats. Biochemical and Biophysical Research Communications 237 476-480.

Denis RGP, Williams G \& Vernon RG 2003 Regulation of serum leptin and its role in the hyperphagia of lactation in the rat. Journal of Endocrinology 176 193-203.

Fei H, Okano HJ, Li C, Lee GH, Zhao C, Darnell R \& Friedman JM 1997 Anatomic localization of alternatively spliced leptin receptors (Ob-R) in mouse brain and other tissues. PNAS 94 7001-7005.

Friedman JM \& Halaas J L 1998 Leptin and the regulation of body weight in mammals. Nature 395 763-770.

Guan XM, Hess JF, Yu H, Hey PJ \& van der Ploeg LH 1997 Differential expression of mRNA for leptin receptor isoforms in the rat brain. Molecular and Cellular Endocrinology 133 1-7.

Hardie LJ, Rayner DV, Holmes S \& Trayhurn P 1996 Circulating leptin levels are modulated by fasting, cold exposure and insulin administration in lean but not Zucker $(\mathrm{fa} / \mathrm{fa}$ ) rats as measured by ELISA. Biochemical and Biophysical Research Communications 223 660-665

Havel PJ 2000 Role of adipose tissue in body-weight regulation: mechanisms regulating leptin production and energy balance. Proceedings of the Nutrition Society 59 359-371. 
Herrera E, Lasuncion MA, Huerta L \& Martin-Hidalgo A 2000 Plasma leptin levels in rat mother and offspring during pregnancy and lactation. Biology of the Neonate 78 315-320.

Hikita M, Bujo H, Hirayama S, Takahashi K, Morisaki N \& Saito Y 2000 Differential regulation of leptin receptor expression by insulin and leptin in neuroblastoma cells. Biochemical and Biophysical Research Communications 271 703-709.

Houseknecht KL, Baile CA, Matteri RL \& Spurlock ME 1998 The biology of leptin: a review. Journal of Animal Science 76 1405-1420.

Huang L, Wang Z \& Li C 2001 Modulation of circulating leptin levels by its soluble receptor. Journal of Biological Chemistry 276 6343-6349.

Johnstone LE \& Higuchi T 2001 Food intake and leptin during pregnancy and lactation. Progress in Brain Research 133 215-227.

Kalsbeek A, Fliers E, Romijn JA, La Fleur SE, Wortel J, Bakker O, Endert E \& Buija RM 2001 The suprachiasmatic nucleus generates the diurnal changes in plasma leptin levels. Endocrinology $\mathbf{1 4 2}$ 2677-2685.

Kastin AJ \& Pan W 2000 Dynamic regulation of leptin entry into brain by the blood-brain barrier. Regulatory Peptides 92 37-43.

Kawai M, Yamaguchi M, Murakami T, Shima K, Murata Y \& Kishi K 1997 The placenta is not the main source of leptin production in pregnant rat: gestational profile of leptin in plasma and adipose tissues. Biochemical and Biophysical Research Communications 240 798-802.

Kimura T, Maji T \& Ashida K 1970 Periodicity of food intake and lipogenesis in rats subjected to two different feeding plans. Journal of Nutrition 100 691-697.

Li C, Ioffe E, Fidahusein N, Connolly E \& Friedman JM 1998 Absence of soluble leptin receptor in plasma from dbPas/dbPas and other db/db mice. Journal of Biological Chemistry 273 10078-10082.

Lollmann B, Gruninger S, Stricker-Krongrad A \& Chiesi M 1997 Detection and quantification of the leptin receptor splice variants $\mathrm{Ob}-\mathrm{Ra}, \mathrm{b}$, and $\mathrm{e}$ in different mouse tissues Biochemical and Biophysical Research Communications 238 648-652.

Martin RL, Perez E, He YJ, Dawson R Jr \& Millard WJ 2000 Leptin resistance is associated with hypothalamic leptin receptor mRNA and protein downregulation. Metabolism 49 1479-1484.

Mastronardi CA, Walczewska A, Yu WH, Karanth S, Parlow AF \& McCann SM 2000 The possible role of prolactin in the circadian rhythm of leptin secretion in male rats. Proceedings of the Society for Experimental Biology and Medicine 224 152-158.

Meister B 2000 Control of food intake via leptin receptors in the hypothalamus. Vitamins and Hormones 59 265-304.

Mercer JG, Moar KM, Rayner DV, Trayhurn P \& Hoggard N 1997 Regulation of leptin receptor and NPY gene expression in hypothalamus of leptin-treated obese $(\mathrm{ob} / \mathrm{ob})$ and cold-exposed lean mice. FEBS Letters 402 185-188.

Munday MR \& Williamson DH 1983 Diurnal variations in food intake and in lipogenesis in mammary gland and liver of lactating rats. Biochemical Journal 214 183-187.

Nagatani S, Guthikonda P \& Foster DL 2000 Appearance of a nocturnal peak of leptin secretion in the pubertal rat. Hormones and Behavior 37 345-352.

Nishiyama MS, Makino S, Suermaru S, Nanamiya WW, Asaba T, Kaneda T, Mimoto T, Nishioka T, Takao T \& Hashimoto K 2000 Glucocorticoid effects on the diurnal rhythm of circulating leptin levels. Hormone Research 54 69-73.

Pickavance L, Tadayyon M, Williams G \& Vernon RG 1998 Lactation suppresses diurnal rhythm of serum leptin. Biochemical and Biophysical Research Communications 248 196-199.

Pu S, Dube MG, Kalra PS \& Kalra SP 2000 Regulation of leptin secretion: effects of aging on daily patterns of serum leptin and food consumption. Regulatory Peptides 92 107-111.

Robertson JP, Faulkner A \& Vernon RG 1982 Regulation of glycolysis and fatty acid synthesis from glucose in sheep adipose tissue. Biochemical Journal 206 577-586.
Saladin R, Vos PD, Guerre-Millo M, Leturque A, Girard J, Staels B \& Auwerx J 1995 Transient increase in obese gene expression after food intake or insulin administration. Nature 377 527-529.

Siegling A, Lehmann M, Platzer C, Emmrich F \& Volk HD 1994 A novel multispecific competitor fragment for quantitative PCR analysis of cytokine gene expression in rats. Journal of Immunological Methods 177 23-28.

Spiegelman BM \& Flier JS 2001 Obesity and the regulation of energy balance. Cell 104 531-543.

Strubbe JH \& Gorissen J 1980 Meal patterning in the lactating rat. Physiology and Behavior 25 775-777.

Tena-Sempere M, Pinilla L, Gonzalez LC, Casanueva FF, Dieguez C \& Aguilar E 2000 Homologous and heterologous down-regulation of leptin receptor messenger ribonucleic acid in rat adrenal gland. Journal of Endocrinology 167 479-486.

Tena-Sempere M, Pinilla L, Zhang FP, Gonzalez LC, Huhtaniemi I, Casanueva FF, Dieguez C \& Aguilar E 2001 Developmental and hormonal regulation of leptin receptor $(\mathrm{Ob}-\mathrm{R})$ messenger ribonucleic acid expression in rat testis. Biology of Reproduction 64 634-643.

Terada Y, Yamakawa K, Sugaya A \& Toyoda N 1998 Serum leptin levels do not rise during pregnancy in age-matched rats. Biochemical and Biophysical Research Communications 253 841-844.

Trayhurn P 1989 Thermogenesis and the energetics of pregnancy and lactation. Canadian Journal of Physiology and Pharmacology 67 370-375.

Uotani S, Bjorbaek C, Tornoe J \& Flier JS 1999 Functional properties of leptin receptor isoforms: internalization and degradation of leptin and ligand-induced receptor downregulation. Diabetes 48 279-286.

Vernon RG \& Pond CM 1997 Adaptations of maternal adipose tissue to lactation. Journal of Mammary Gland Biology and Neoplasia 2 231-241.

Vernon RG, Denis RGP \& Sorensen A 2001 Signals of adiposity. Domestic Animal Endocrinology 21 197-214.

Wade GN \& Schneider JE 1992 Metabolic fuels and reproduction in female mammals. Neuroscience and Behaviour Review 16 235-272.

Wang MW, Zhou YT, Newgard CB \& Unger RH 1996 A novel leptin receptor isoform in rat. FEBS Letters 392 87-90.

White DW, Kuropatwinski KK, Devos R, Baumann H \& Tartaglia LA 1997 Leptin receptor (OB-R) signaling. Cytoplasmic domain mutational analysis and evidence for receptor homo-oligomerization Journal of Biological Chemistry 272 4065-4071.

Williams G, Steel JH, Cardoso H, Ghatei MA, Lee YC, Gill JS, Burrin JM, Polak JM \& Bloom SR 1988 Increased hypothalamic neuropeptide Y concentrations in diabetic rat. Diabetes 37 763-772.

Williams G, Bing C, Cai XJ, Harold JA, King PJ \& Liu LH 2001 The hypothalamus and the control of energy homeostasis: different circuits, different purposes. Physiology and Behaviour 74 683-701.

Woodside B, Abizaid A \& Jafferali S 1998 Effect of acute food deprivation on lactational infertility in rats is reduced by leptin administration. American Journal of Physiology 274 R1653-R1658.

Woodside B, Abizaid A \& Walker C 2000 Changes in leptin levels during lactation: implications for lactational hyperphagia and anovulation. Hormones and Behavior 37 353-365.

Xu B, Kalra PS, Farmerie WG \& Kalra SP 1999 Daily changes in hypothalamic gene expression of neuropeptide $\mathrm{Y}$, galanin, proopiomelanocortin and adipocyte leptin gene expression and secretion: effects of food restriction. Endocrinology 140 2868-2875.

Zhang Y, Proenca R, Barone M, Leopold L \& Friedman JM 1994 Positional cloning of the mouse obese gene and its human homologue. Nature 372 425-432.

Received in final form 16 April 2003

Accepted 29 April 2003

Made available online as an Accepted Preprint

7 May 2003 